\title{
Skin tests in bird breeder's disease
}

\author{
FERRAN MORELL, VICTOR CURULL, RAMON ORRIOLS, JAVIER DE GRACIA
}

From the Seccio de Pneumologia, Hospital General Vall d'Hebron, Barcelona, Spain

ABSTRACT The diagnostic value of skin tests was assessed in 35 patients affected by bird breeder's disease by comparing the results with those obtained in a group of 27 symptomless breeders and $10 \stackrel{乛}{7}$ symptomless unexposed individuals. Sterilised and diluted serum and lyophilised extracts of faeces prepared from the breeder's own birds were injected intradermally. Skinprick tests using the same materials were carried out simultaneously. The intradermal test using serum showed a positive iv reaction in 18 out of 20 patients tested and in three out of 20 symptomless breeders $(p<0.0005) ; \infty$ later reactions occurred in eight of the patients and one of the symptomless breeders $(p<0.01)$. $A$ 음 delayed reaction was seen in five of the patients and one of the symptomless breeders $(p=0.09)$. No $\vec{c}$ positive reactions were recorded in symptomless unexposed individuals. Intradermal skin testing using extracts of faeces yielded an immediate reaction in 19 of 21 patients and in three of $11 \frac{\overrightarrow{0}}{2}$ symptomless breeders tested ( $\mathrm{p}<0.001$ ); a late reaction was seen in 18 of the patients and in five $\mathscr{O}_{\sigma}^{\circ}$ of the symptomless breeders $(\mathrm{p}<0.05)$. Delayed reactions occurred in 11 of the 21 patients tested, whereas no positive responses were seen in symptomless breeders $(p<0.025)$. Skinprick tests gave negative results in all cases. Skin testing constitutes a simple, quick, and safe procedure that can assist the differential diagnosis between individuals with bird breeder's disease and symptomless breeders, the immediate reaction being similar in its sensitivity to testing for serum precipitins but $\frac{O}{\mathbb{}}$ possessing greater specificity.

Bird breeder's disease is one of the most frequently diagnosed forms of extrinsic allergic alveolitis in urban environments. The responsible antigens are found in the serum proteins, excrement, and feathers of birds. ${ }^{1}$ The diagnosis of bird breeder's disease is simple if the patient is suffering from the acute phase of the disease, but may be more difficult in chronic forms, where the clinical picture is of pulmonary fibrosis or chronic bronchitis.

The detection of specific precipitins in the serum of these patients is a very sensitive method of detection but its effectiveness is low, because of the large number of false positive results. ${ }^{23}$ The test for inhibition of leucocyte migration, ${ }^{4}$ which is much more specific, has the drawbacks of high cost and complexity, which puts it beyond the reach of many laboratories. A quick and simple method is therefore called for in the diagnosis of this disease. Although studies of skin tests have been undertaken by several workers, ${ }^{15-13}$ the disparity of results and lack of standardisation of the technique, as well as the absence of comparative

\footnotetext{
Address for reprint requests: Dr F Morell, Seccio de Pneumologia, Hospital General Vall d'Hebron, $P$ Vall d'Hebron s/n, 08035 Barcelona, Spain.
}

Accepted 10 January 1986 studies between large groups of patients and symp tomless individuals in contact with birds, promptedo us to analyse our experience with skin tests using bird serum and an extract of faeces in a group of patientso affected by bird breeder's disease, and to compare the results with those obtained in symptomless breeders. $\frac{.}{3}$

\section{Methods}

SUBJECTS

Thirty five patients (mean age 45.6, range 13-64 years) affected by bird breeder's disease were studied. The diagnosis was based on clinical, functional, radio-n logical, and immunological criteria. All patients reported contact with birds and a history of exer ${ }^{N}$ tional dyspnoea and most of them had experienced at least one episode of dyspnoea a few hours after contact with birds. Chest radiographs showed a diffuse interstitial pattern in all patients. The study of lungo function showed a restrictive pattern in $15(42.8 \%)$ of the patients. Carbon monoxide transfer factor wast decreased in $28(93.3 \%)$ cases. Tests for specific serum? precipitins using a counterimmunoelectrophoresis technique, with either serum or faeces, gave positive results in $32(91.4 \%)$ patients. An inhalation provocation test, using a Bird Mark 4 ventilator to nebulise 
$\mathrm{ml}$ of sterilized bird serum or faeces extract at 1:100 in saline solution (and repeated at 1:10 in the event of a negative result), was performed on 21 patients and gave positive results in $20(95.2 \%)$. Only one of the patients had bronchial asthma in addition to alveolitis.

Twenty seven symptomless bird breeders (mean age 49.3, range 19-66 years) formed the control group. None of them reported respiratory symptoms related to contact with birds. The chest radiographs showed no features suggestive of extrinsic allergic alveolitis. Serum precipitins were detected in $22(81.4 \%)$ of the symptomless breeders.

A group of 10 symptomless individuals not exposed to birds was also tested (mean age 34.7 range 20-45 years).

\section{PREPARATION OF THE ANTIGEN}

The antigen extracts were prepared with serum or faeces from every patients' own birds as follows. Bird blood, obtained by venepuncture, was centrifuged and diluted 1:100 in distilled water and then sterilised, a Millipore filter being used $(0.24 \mu \mathrm{m})$. Faeces were placed in ether for 24 hours and then allowed to evaporate for lipid extraction. The material was subsequently mixed with Coca's solution for seven days. Afterwards the solution was passed through a Seitz filter and then dialysed, freeze dried, and stored at room temperature. The resulting extract was dissolved in distilled water and used at a concentration of $100 \mathrm{mg} / \mathrm{ml}$ for precipitin detection and $1 \mathrm{mg} / \mathrm{ml}$ for skin tests.

\section{SKIN TESTS}

Skin tests were performed in the acute phase of the disease by means of intradermal injection into the forearm. About $0.1 \mathrm{ml}$ was injected to form a $5 \mathrm{~mm}$ weal. This was done in 20 patients with bird serum and in 21 patients with faeces extract (the test was made with both solutions simultaneously in six of 35 cases). Skin tests were performed in 20 symptomless breeders with serum and in 11 with faeces (four were tested with both solutions). All tests in symptomless unexposed individuals were carried out with bird serum. The test was read after 15 minutes (immediate reaction), after four to six hours (late reaction), and after 48 hours (delayed reaction). The test was considered positive when the weal diameter was greater than
$10 \mathrm{~mm}$ in the immediate reaction, and when induration was greater than $10 \mathrm{~mm}$ in the late and delayed reactions. The skinprick test was applied simultaneously in all cases. In 10 of the patients affected by bird breeder's disease skin tests were repeated with bird serum at least one year after exposure to birds had ceased.

STATISTICAL ANALYSIS

For statistical analysis of the results we used the one tailed $\chi^{2}$ test with Yates's correction, applying the exact formula of Fisher if necessary. Sensitivity, specificity, and predictive value have been calculated as usual. ${ }^{14}$

\section{Results}

INTRADERMAL SKIN TESTS WITH BIRD SERUM (table 1)

A positive immediate reaction was seen in $18(90 \%)$ of the 20 patients with bird breeder's disease and in three $(15 \%)$ of the 20 symptomless breeders $(\mathrm{p}<0.0005)$. Late responses occurred in eight $(40 \%)$ patients and in one $(5 \%)$ of the symptomless breeders $(p<0.01)$. A delayed reaction was seen in five patients and in one symptomless breeder $(p=0.09)$. No positive reactions were detected in symptomless unexposed individuals. The sensitivity, specificity, and predictive value of the test are displayed in table 2 .

\section{INTRADERMAL SKIN TESTS WITH BIRD FAECES EXTRACT}

The results of intradermal skin tests with bird faeces are summarised in table 3 and the sensitivity, specificity, and predictive value are shown in table 4 . A high proportion of the patients with bird breeder's disease had positive immediate and late reactions

Table 1 Positivity of intradermal skin tests with the birds' serum

\begin{tabular}{llll}
\hline Reaction & No $(\%)$ positive & $p$ \\
\cline { 2 - 3 } & Patients $(n=20)$ & $\begin{array}{l}\text { Symptomless } \\
\text { breeders }(n=20)\end{array}$ \\
\hline Immediate & $18(90)$ & $3(15)$ & $<0.0005^{*}$ \\
Late & $8(40)$ & $1(5)$ & $<0.01^{*}$ \\
Delayed & $5(25)$ & $1(5)$ & $0.09^{* *}$ \\
\hline
\end{tabular}

*One tailed $\chi^{2}$ test with Yates's correction.

**Exact formula of Fisher.

Table 2 Sensitivity, specificity, and predictive value of intradermal skin tests with the birds' serum

\begin{tabular}{llll}
\hline Reaction & Sensitivity & Specificity & PPV \\
\hline Immediate & $90 \%(18 / 20)$ & $85 \%(17 / 20)$ & $85 \%(18 / 21)$ \\
Late & $40 \%(8 / 20)$ & $95 \%(19 / 20)$ & $88 \%(8 / 9)$ \\
Delayed & $25 \%(5 / 20)$ & $95 \%(19 / 20)$ & $83 \%(5 / 6)$ \\
\hline
\end{tabular}

PPV-positive predictive value; NPV-negative predictive value. 
Table 3 Positivity of intradermal skin tests with the birds' faeces extract

\begin{tabular}{llll}
\hline Reaction & No $(\%)$ positive & \multirow{2}{*}{$p^{*}$} \\
\cline { 2 - 3 } & Patients $(n=21)$ & $\begin{array}{l}\text { Symptomless } \\
\text { breeders }(n=11)\end{array}$ \\
\hline Immediate & $19(90.4)$ & $3(27.2)$ & $<0.001$ \\
Late & $18(85.7)$ & $5(45.4)$ & $<0.05$ \\
Delayed & $11(52.3)$ & & $<0.025$ \\
\hline *One tailed $\chi^{2}$ test with Yates's correction &
\end{tabular}

whereas only about a quarter of the symptomless breeders had immediate reactions and half had late reactions. Positive delayed reactions were seen in eleven of the 21 patients with bird breeder's disease $(52 \%)$ and in none of the symptomless breeders.

\section{SKINPRICK TESTS WITH BIRD SERUM AND}

FAECES EXTRACT

Skinprick testing, both with serum and with faeces extract, gave negative results in all patients with bird breeder's disease and in all symptomless breeders and unexposed individuals.

INTRADERMAL SKIN TESTS WITH BIRD SERUM AFTER REMOVAL FROM EXPOSURE TO BIRDS Intradermal skin tests using bird serum were repeated in 10 patients with bird breeder's disease after they had been removed from contact with birds for at least one year. The results are summarised in table 5. Of the 10 patients, nine had had immediate reactions before withdrawal from exposure and four still had immediate reactions when retested. Five had had late reactions before withdrawal and one was found to have a late reaction on being retested. Four patients had had delayed reactions before withdrawal and none of these had delayed reactions when retested more than a year after withdrawal from contact with birds.

\section{Discussion}

The diagnosis of bird breeder's disease is based on a history of contact with birds, together with clinical, radiological, and lung function findings. It must be confirmed by immunological tests, among which the most used is the detection of serum precipitins, which is a very sensitive test, but has low specificity. ${ }^{23}$
Table 5 Positivity of intradermal skin tests with the birds' serum during exposure to birds and after one year without exposure

\begin{tabular}{llll}
\hline Reaction & \multicolumn{2}{l}{ No $(\%)$ positive } & $p^{*}$ \\
\cline { 2 - 4 } & $\begin{array}{l}\text { Exposed } \\
\text { patients } \\
(n=10)\end{array}$ & $\begin{array}{l}\text { Non-exposed } \\
\text { patients } \\
(n=10)\end{array}$ & \\
\hline Immediate & $9(90)$ & $4(40)$ & $<0.025$ \\
Late & $5(50)$ & $1(10)$ & 0.07 \\
Delayed & $4(40)$ & 0 & $<0.05$ \\
\hline
\end{tabular}

*Exact formula of Fisher.

Inhalation tests, used to confirm the diagnosis,

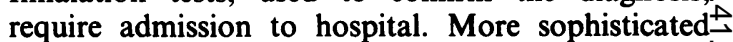
methods, such as the macrophage migration inhibition test, ${ }^{4}$ have been tried with good results. These are, however, beyond the reach of many labo- -0 ratories. It is therefore desirable to have available simple, quick, and effective methods for the diagnosis $\vec{C}$ of this condition that may also be used on an outpatient basis.

Skin tests have been studied by several workers, $\vec{\oplus}$ with varied results. ${ }^{15-13}$ Special attention has been ${ }^{\circ}$ paid to the late reaction, which has been considered to be the most specific test for the diagnosis. ${ }^{15}$ Never theless, several studies report positive results associated with an immediate reaction. ${ }^{15-79-13}$ iMost of these studies have been carried out on a small number of patients and controls, and some have had no con $\overrightarrow{2}$ trol group.

Fink, ${ }^{16}$ using pigeon serum, found positive immediate reactions in $80 \%$ of his patients. Other studz ies, ${ }^{11} 17$ with a larger number of patients and con trols, have been performed with heterogeneouso groups such as "allergic to birds" or "symptomatics' - without clear definition of the inclusion criteriao On the basis of these data, we conclude that, in gen? eral, results of skin tests have been found to be posio tive in bird breeder's disease, but that their diagnostice usefulness has not been supported by studies of large? groups of patients compared with symptomless breeders.

Our results suggest that skin tests are effective in discriminating between patients and symptomless breeders, especially in the case of the immediate reaction, both with serum and with faeces extract Although the simplicity of obtaining bird serum and its higher specificity makes it preferable, the choice of

Table 4 Sensitivity, specificity, and predictive value of intradermal skin tests with extracts of the birds' faeces

\begin{tabular}{lllll}
\hline Reaction & Sensitivity & Specificity & PPV & NPV \\
\hline Immediate & $90.4 \%(19 / 21)$ & $72.7 \%(8 / 11)$ & $86.3 \%(19 / 22)$ & $80 \%(8 / 10)$ \\
Late & $85.7 \%(18 / 21)$ & $54.5 \%(6 / 11)$ & $78.2 \%(18 / 23)$ & $66.6 \%(6 / 9)$ \\
Delayed & $52.3 \%(11 / 21)$ & $100 \%(11 / 11)$ & $100 \%(11 / 11)$ & $52.3 \%(11 / 21)$ \\
\hline PPV_positive predictive value; NPV-negative predictive value. & & $\stackrel{\bigcirc}{\Phi}$ \\
\hline
\end{tabular}

PPV-positive predictive value; NPV-negative predictive value. 
material depends on availability.

Late and delayed reactions, despite their lesser sensitivity, can contribute to the differential diagnosis between patients and symptomless breeders, improving the overall diagnostic performance of the test. Positivity in all three forms of reaction suggest that several immunological mechanisms play a part in the pathogenesis of this disease.

The role of type III and type IV hypersensitivity, in the Gell and Coombs classification, in the pathogenesis of hypersensitivity pneumonitis, is well known. ${ }^{11018}$ Immediate hypersensitivity has been considered less often. ${ }^{1920}$ The present study shows a close association between immediate reactions and bird breeder's disease. Nevertheless, this type I hypersensitivity is probably not mediated by IgE, as suggested by the absence of atopic history, normal serum IgE values, and normal serum specific IgE values reported by Faux et al. ${ }^{2}$ Furthermore, the negative skinprick test reaction but positive intradermal immediate reaction argue in favour of the role of an IgG subclass rather than IgE in the mediation of this type of immediate hypersensitivity. ${ }^{21}$

This study also shows the absence of irritant effect due to the antigen solution we used, since none of the non-exposed group had reactions. The reactions found in symptomless breeders are therefore attributable to an immunological response to exposure to birds. It is interesting that skin reactivity was lost when exposure to birds had ceased. This has not been reported before, and could be related to the disappearance of serum precipitin after exposure to birds has ceased for some time. ${ }^{22}$ We speculated that the same antibody could be responsible for both the precipitin reaction and the immediate skin reaction. In fact, McSharry et al showed a correlation between serum IgG antibody titre against pigeon serum gammaglobulin antigen and skin reaction diameter. ${ }^{20}$

We conclude from our results that skin tests constitute a simple, quick, and safe procedure; no adverse reactions were encountered in any case. The immediate reaction is similar in its sensitivity to serum precipitin detection, and it possesses a specificity greatly superior to that of the latter. These considerations should make skin tests a valuable and routinely used method in the differential diagnosis between patients with bird breeder's disease and individuals exposed to birds who do not have the disease.

\section{References}

1 Pepys J. Hypersensitivity diseases of the lungs due to fungi and organic dusts. Basel: S Karger, 1969: (Monographs in allergy. Vol 4.)

2 Faux JA, Wells ID, Pepys J. Specificity of avian serum proteins in test against the sera of bird fanciers. Clin Allergy 1971;1:159-70.

3 Barboriak JJ, Fink JN, Sosman AJ. Precipitating antibody against pigeon. Antigens in sera of asymptomatic pigeon breeders. J Lab Clin Med 1973;82:372-6.

4 Morell F, Orriols R, Antó JM, Roig J, Sanjuas C, Morera J. El test de inhibicion de la migracion de los leucocitos en el pulmon del cuidador de aves. Allergol Immunopathol 1980; suppl 7:115-7.

5 Hargreave FE, Pepys J, Longbottom JL, Wraith DG. Bird breeder's (fancier's) lung. Lancet 1966;i:445-9.

6 Fink JN, Sosman AJ, Barboriak JJ, Schlueter DP, Holmes RA. Pigeon breeders' disease. A clinical study of a hypersensitivity pneumonitis. Ann Intern Med 1968;68:1205-19.

7 Turner Warwick M, Haslam P. Antibodies in some chronic fibrosing lung diseases. I. Non organ-specific autoantibodies. Clin Allergy 1971;1:209-19.

8 Wenzel FJ, Emanuel DA, Gray RL. Immunofluorescent studies in patients with farmer's lung. $J$ Allergy Clin Immunol 1971;48:224-9.

9 Bach CH, Fournier C, Drouchet E, et al. La maladie des eleveurs d'oiseaux chez l'enfant. Presse Med 1971;79: 383-6.

10 Caldwell JR, Pearce DE, Spencer C, Leder R, Waldman RH. Immunologic mechanisms in hypersensitivity pneumonitis. I. Evidence for cell-mediated immunity and complement fixation in pigeon breeders' disease. $J$ Allergy Clin Immunol 1973;52:225-30.

11 Boyer RS, Clock LE, Schmidt D, et al. Hypersensitivity lung disease in the turkey raising industry. Am Rev Respir Dis 1974;109:630-5.

12 Moore VL, Fink JN. Immunologic studies in hypersensitivity pneumonitis-quantitative precipitins and complement-fixing antibodies in symptomatic and asymptomatic pigeon breeders. J Lab Clin Med 1975; 85:540-5.

13 Warren CPW, Cherniack RM, Tse KS. Extrinsic allergic alveolitis from bird exposure. Studies on the immediate hypersensitivity reaction. Clin Allergy 1977;7:303-14.

14 Griner PF, Mayewski RJ, Mushlin AI, Greenland PG. Selection and interpretation of diagnostic tests and procedures. Ann Intern Med 1981;94:553-92.

15 Pepys J. Skin Test in diagnosis. In: Gell PGH, Coombs RRA, Lachmann PJ, eds. Clinical aspects of immunology. Oxford: Blackwell, 1975:52.

16 Fink JN. Hypersensitivity pneumonitis. J Allergy Clin Immunol 1973;52:309-17.

17 Hargreave FE, Pepys J. Allergic respiratory reactions in bird fanciers provoked by allergen inhalation provocation tests. Relation to clinical features and allergic mechanisms. J Allergy Clin Immunol 1972;50:157-73.

18 Morell F, Jeanneret A, Aiache JM, Molina C. Leukocyte migration inhibition in farmer's lung. $J$ Allergy Clin Immunol 1982;69:405-9.

19 Morell F, Orriols R, Jeanneret A, Aiache JM, Molina C. Hypersensibilité immediate et alveolites allergiques extrinseques. Rev Fr Allergol 1982;22:91-5.

20 McSharry C, Banham SW, Lynch PP, Boyd G. Skin testing and extrinsic allergic alveolitis. Clin Exp Immunol 1983;54:282-8.

21 Parish WE. Short-term anaphylactic IgE antibodies in human sera. Lancet 1970;ii:591-2.

22 Fink JN, Barboriak JJ, Sosman AJ. Immunological studies in pigeon breeder's disease. $J$ Allergy 1967; 39:214-21. : 